\title{
UPAYA PENINGKATAN KINERJA GURU MATA PELAJARAN DI KELAS MELALUI IMPLEMENTASI SUPERVISI EKSTERNAL DI SMK NEGERI 5 MEDAN
}

\author{
Edison \\ Sekolah Menengah Kejuruan Negeri 5 Medan, Sumatera Utara \\ edison@gmail.com
}

\begin{abstract}
Abstrak: Penelitian bertujuan untuk meningkatkan kinerja guru mata pelajaran dalam kegiatan pembelajaran di Kelas, menjelaskan langkah-langkah supervisi edukatif eksternal secara periodik dalam menyusun rencana pembelajaran, menjelaskan langkah-langkah supervisi edukatif eksternal secara periodik dalam pelaksanaan pembelajaran, menjelaskan langkah-langkah supervisi edukatif eksternal secara periodik dalam melaksaksanakan evaluasi pembelajaran, menjelaskan langkah-langkah supervisi edukatif eksternal secara periodik dalam melaksanakan tindaklanjut pembelajaran (program remedial dan pengayaan). Hasil penelitian menunjukkan bahwa: kinerja guru meningkat setelah dilakukan supervisi eksternal dalam menyusun rencana, melaksanakan pembelajaran, penilaian dan tindak lanjut pada siklus pertama dan kedua. Berdasarkan hasil Penelititan kinerja guru meningkat pada; menyusun rencana pembelajaran pada siklus I $64 \%$ naik pada siklus II menjadi $94 \%$; melaksanakan pembelajaran pada siklus I $61 \%$ naik pada siklus II menjadi $88 \%$; menilai prestasi Belajar pada siklus $81 \%$ naik pada siklus II menjadi $97 \%$; melakukan tindak lanjut pada siklus I $49 \%$ naik pada siklus II menjadi $78 \%$.
\end{abstract}

Kata Kunci: implementasi supervisi eksternal, dinas pendidikan, meningkatkan kinerja guru

\begin{abstract}
The research aims to improve the performance of subject teachers in learning activities in class, explaining the steps supervision educative external periodic basis in preparing lesson plans, explain the steps supervision educative external periodically in the implementation of learning, explains the steps supervision educative external periodically in melaksaksanakan evaluation of learning, explains the steps periodic external educational supervision in carrying out a follow-up study (remedial and enrichment programs). The results showed that: the performance of teachers increased after external supervision in planning, implementing learning, assessment and follow-up on the first and second cycles. Based on the results Penelititan teacher performance increase on; prepare a lesson plan on the first cycle $64 \%$ rise in the second cycle to 94\%; implementing learning in the first cycle $61 \%$ rise in the second cycle to $88 \%$; Learning to assess achievement in cycle $81 \%$ rise in the second cycle to 97\%; to follow up on the first cycle $49 \%$ rise in the second cycle to $78 \%$.
\end{abstract}

Keywords: implementation of external supervisors, department of education, improving teacher performance

\section{PENDAHULUAN}

Pembangunan memerlukan tenaga penggerak sebagai motor yang menggerakkan semua aspek dari pembangunan tersebut. Tenaga pengerak tersebut ialah manusia yang mempunyai keahlian (skill), tanpa keahlian pembangunan itu tidak akan berjalan lancar. Tenaga ahli itu dihasilkan oleh pendidikan, karena itu pendidikan memegang peranan penting dalam mencapai tujuan negara, yaitu masyarakat adil dan makmur. Pemikiran tentang pentingnya pendidikan sudah dimulai sebelum Indonesia merdeka,
Menurut Syamsuddin (2005: 66) ada tiga komponen utama yang saling berkaitan dan memiliki kedudukan strategis dalam kegiatan belajar- mengajar. Ketiga komponen tersebut yaitu: Kurikulum, guru mata pelajaran dan pembelajar. Dalam kegiatan pembelajaran seorang guru mata pelajaran harus mampu menterjemahkan nilai-nilai yang terkandung dalam kurikulum secara optimal. Walaupun saat ini sistem pembelajaran tidak bersifat guru mata pelajaran sebagai pusat belajar, seorang guru mata pelajaran harus tetap memegang peranan penting dalam membimbing siswa. Menurut Undang-undang 
Guru pasal 1 ayat 1 (2006: 3) guru adalah pendidik profesional dengan tugas utama mendidik, mengajar, membimbing, mengarahkan, melatih, menilai dan mengevaluasi peserta didik pada pendidikan usia dini jalur pendidikan formal, pendidikan dasar, pendidikan menengah. Berdasarkan hal itu , seorang guru mata pelajaran harus mempunyai pengetahuan yang memadai baik di bidang akademik maupun pedagogik.

Keempat kompetensi bertujuan agar guru mata pelajaran bermutu menjadikan pembelajaran bermutu juga yang akhirnya meningkatkan mutu pendidikan . Untuk mencapai empat kompetensi tersebut, sekolah harus melaksanakan pembinaan, evaluasi dan pengawasan terhadap kinerja guru mata pelajaran baik melalui wokshop, MGMP, Praktek Kerja Guru (PKG), supervisi yang bertujuan untuk memperbaiki proses pembelajaran cenderung menitikberatkan pada aspek administrasi.

Di SMK N 5 Medan memiliki rombongan belajar (rombel) 25 kelas dengan jumlah guru mata pelajaran 69 orang dan jumlah siswa 898 orang. Jam belajar mulai Jam 07.15 s/d 14.00 Istirahat dua kali masing-masing selama 15 menit. Dalam kegiatan pembelajaran sebagian siswa terlambat masuk, tidak minat mengikuti kegiatan pembelajaran, siswa ribut, kelas sebagian ada yang guru mata pelajarannya tidak masuk dan beberapa kendala lainnya. Sedangkan Khusus bagi Guru mata pelajaran di SMK N 5 Medan ada beberapa masalah yang harus dipecahkan, antara lain :

1. Sebagian tidak memiliki perangkat pembelajaran, daftar nilai tidak lengkap dan absensi siswa kurang lengkap.

2. Sebagian guru mata pelajaran terlambat masuk kelas, terutama pada jam pertama Pelajaran.

3. Sebagian Guru mata pelajaran Tidak memiliki perangkat pembelajaran yang lengkap.

4. Sebagian Guru mata pelajaran Tidak menguasai Model-model Pembelajaran.

5. Sebagian Guru mata pelajaran Tidak memberikan laporan nilai hasil evaluasi belajar yang objektif.

6. Sebagian guru mata pelajaran sudah keluar kelas padahal belum habis jam belajarnya.
7. Sebagian guru mata pelajaran meninggalkan kelas dan ngobrol sesama guru mata pelajaran di kelas sebelahnya saat kegiatan pembelajaran.

8. Sebagian guru mata pelajaran kurang memahami kondisi anak didiknya.

9. Sebagian guru mata pelajaran kurang dalam memberikan penghargaan kepada siswa misalnya hasil ulangan tidak dikoreksi tentunya tidak ada nilainya.

10.Sebagian Guru mata pelajaran tidak melaksanakan tindak lanjut hasil analisis penilaian.

11.Sebagian guru mata pelajaran belum menyadari akan tugas guru mata pelajaran yang sebenarnya.

Undang-Undang Sistem Pendidikan

Nomor 20 Tahun 2003, Seseorang yang bekerja di dunia pendidikan baik formal, nonformal, maupun Informal harus mempunyai kamampuan khusus dibidang kepandidikan itu. Secara umum, guru mata pelajaran tersebut harus berkompetensi dibidangnya. Oleh sebab itu, untuk mengetahui bagai mana kompetensi seorang ahli kependidikan, yang di dalamnya adalah guru , kepala sekolah, dan pengelola sekolah, pada kajian teori ini akan dibahas tentang kompetensi guru mata pelajaran, kinerja guru mata pelajaran, supervisi edukatif, dan hipotesis tindakan.

Sesuai dengan Undang-Undang tentang Sistem Pendidikan Nasional , Kompetensi merupakan spesifikasi dari kemampuan keterampilan, dan sikap yang di miliki seseorang serta penerapannya di dalam pekerjaan, sesuai dengan Standart kinerja yang dibutuhkan oleh lapangan, (Ditjen Dikdasmen, 2004: 4). Berdasarkan pendapat tersebut seorang yang bekerja sebagai guru mata pelajaran, yang menurut UndangUndang Guru Tahun 2005 merupakan pekerjaan professional, guru mata pelajaran harus memenuhi Standar-standar minimal yang di butuhkan oleh Kementrian Pendidikan dan Kebudayaan (Kemendikbud).

Guru mata pelajaran yang setiap hari selalu berhadapan dengan anak tentu menghadapi berbagai masalah, baik yang berkaitan dengan anak tersebut maupun dengan lingkungan pendidikan, yang notabene mempunyai berbagai karakter, berbagai kemampuan dan motivasi, yang semaunya 
memerlukan strategi-strategi khusus yang harus dipersiapkan oleh guru mata pelajaran, sehingga guru mata pelajaran tersebut harus mempersiapakan diri, baik berkaitan dengan materi yang akan dikuasai siswa, sikap siswa, maupun srategi yang dapat memudahkan siswa dalam memahami materi tersebut. Berdasarkan hal tersebut, Kementrian Pendidikan dan Kebudayaan (Kemendikbud) menentukan bagian-bagian yang harus di kuasai oleh guru mata pelajaran dalam rangka memenuhi Standar Kompetensi Guru mata pelajaran. Kompeten-kompeten standar kopetensi guru mata pelajaran, antara lain: (1) Kompeten kompetensi pengelolaan pembelajaran dan wawasan pendidikan, (2) Kompeten kompetensi Akademik/Vokasional sesuai materi pembelajaran, Pemgembangan profesi.

Selain ketiga kompeten tersebut, seorang guru mata pelajaran harus memiliki sikap dan kepribadian yang positif, dimana sikap dan kepribadian tersebut senantiasa melekat pada setiap kompeten yang menunjang profesi guru mata pelajaran.

Seorang guru mata pelajaran yang professional sikap dan kinerjanya akan kelihatan dalam kehidupan sehari-hari. Semua hasil kerjanya harus diukur oleh indikator. Oleh sebab itu, Ditjen Dikdasmen (2004: 10 ) merumuskan indikator kompetensi yang masing-masing komponen tersebut adalah sebagai berikut.

Kompeten Kompetensi pengelolaan pembelajaran. Kompetensi ini merupakan komponen awal yang harus dilakukan oleh guru mata pelajaran, karena bagian inilah seorang Profesional dalam melaksanakan tugasnya harus berdasarkan program-program yang disiapkan. Dengan adanya program itu, semua akan dapat di nilai, di ukur, dan dievaluasi. Dalam dunia pendidikan, penentuan keberhasilan dapat dilihat dari indikatornya. Oleh sebab itu, indikator dalam kompetensi ini menurut Ditjen Dikmenum adalah sebagai berikut.

Kompetensi menyusun rencana pembalajaran, dengan indikator sebagai berikut; (1) Mendeskripsikan tujuan pembelajaran; (2) Menentukan meteri sesuai dengan kompetensi yang telah di tentukan; (3) Mengorganisasikan meteri berdasarkan urutan dan kelompok; (4) Mengalokasikan waktu; (5)
Menentukan metode pembelajaran yang sesuai; (6) Merancang prosedur pembelajaran; (7) Menentukan media pembelajaran/peralatan praktikum (dan bahan) yang akan di gunakan; (8) Menentukan sumber belajar yang sesuai (berupa buku, modul, LKS, program komputer, dan sejenisnya); (9) Menentukan teknik penilaian.

Kompetensi melaksanakan pembelajaran dengan indikator sebagai berikut: (1) Membuka pelajaran dengan metode yang sesuai; (2) Menyajikan materi pembelajaran secara otomatis; (3) Menerapkan metode dan prosedur pembelajaran yang telah di tentukan; (4) Mengatur kegiatan siswa di kelas; (5) Menggunakan media pembelajaran / peralatan praktikum (dan bahan) yang telah ditentukan; (6) Menggunakan sumber belajar yang telah dipilih (berupa buku, modul, LKS, program komputer, dan sejenisnya); (7) Memotivasi siswa dengan berbagai cara yang positif; (8) Mekakukan interaksi dengan siswa menggunakan bahasa yang komunikatif; (9) Memberikan pertanyaan dan umpan - balik, untuk mengetahui dan memperkuat penerimaan siswa dalam proses belajar; (10) Menyimpulkan pembelajaran; (11) Menggunakan waktu secara efektif dan efisien.

Berdasarkan indikator di atas, guru mata pelajaran harus mampu mendidik, mengajar, membimbing, mengarahkan, melatih dan menilai siswa dalam belajar. Indikator-indikator diatas berkaitan dengan tindakan guru mata pelajaran dalam melaksanakan pembelajaran (KBM). Oleh sebab itu, guru mata pelajaran yang mampu melaksanakan indikator diatas akan dapat menghasilkan pendidikan yang bermutu.

Kompetensi menilai prestasi belajar dengan indikator sebagai berikut; (1) Menyusun soal/ perangkat penilaian sesuai dengan indikator/ kriteria untuk kerja yang telah ditentukan; (2) Melaksanakan penilaian; (3) Memeriksa jawaban/ memberikan skor tes hasil belajar berdasarkan indikator/ kriteria unjuk kerja yang telah ditentukan; (4) Mengelola hasil penilaian; (5) Menganalisis hasil penilaian ( berdasarkan tingkat kesukaran, daya pembeda validitas, reabilitas); (6) Menyimpulkan hasil penilaian secara jelas dan logis ( Misalnya : 
interprestasi kecenderungan hasil penilaian, tingkat pencapain siswa, dll); (7) Menyusun laporan hasil penilaian; (8) Memperbaiki soal/ perangkat penilaian.

Berdasarkan indikator kompetensi penilaian, guru mata pelajaran harus mampu menyusun kisi-kisi, butir soal, pedoman penilaian, melaksanakan, mengolah nilai, melaporkan nilai, dan analisis soal tersebut. Melaksanakan tindak lanjut hasil penilaian prestasi belajar peserta didik dengan indikator sebagai berikut; (1) Mengidentifikasi kebutuhan tindak lanjut hasil penilaian; (2) Menyusun program tindak lanjut hasil penialaian; (3) Melaksanakan tindak lanjut; (4) Mengevaluasi hasil tindak lanjut; (5) Menganalisis hasil evaluasi program tindak lanjut penilaian.

Komponen Kompetensi Wawasan Pendidikan. Kompetensi Wawasan pendidikan merupakan bagian yang harus di kuasai guru mata pelajaran sebelum action di depan anak. Guru mata pelajaran harus memahami landasan pendidikan kebijakan pendidikan, perkembangan siswa, pendekatan pembelajaran, penerapan bekerja sama dalam pekerjaan, dan memanfaatkan kemajuan IPTEK dalam pendidikan. Untuk memahami tersebut, guru mata pelajaran wajib belajar perkembangan ilmu pendidikan dan pengetahuan karena ilmu pendidikan sekarang berkembang dengan pesat. Dahulu pembelajaran, dengan system teacher center sangat tepat, tetapi pembelajaran itu sekarang ternyata kurang tepat karena siswa setelah pembelajaran tidak bisa memecahkan persoalan, bahkan siswa diberi soal yang berbeda walaupun sama temannya tetap tidak bisa. Oleh sebab itu, pembelajar yang berbasis CTL, CL, PAIKEM, Pembelajaran Metode Quantum Teaching perlu dibaca oleh guru mata pelajaran agar wawasan pendidikan terus bertambah. Bahkan, dalam buku-buku pendidikan modern, pembelajaran selalu dikaitkan dengan usia dan motivasi. Berdasarkan uraian diatas, guru mata pelajaran perlu mengetahui dan menguasai indikator-indikator yang berkaitan dengan kompetensi wawasan.

Kompetensi Akademik/Vokasional. Kompetensi akademik berkaitan dengan penguasaan materi pelajaran yang akan dipelajari / dipahami/dikuasai siswa. Guru mata pelajaran harus menguasai materi yang akan diajarkan. Oleh sebab itu kompetensi bidang akademik ini berkaitan dengan penguasaan keterampilan sesuai dengan materi pembelajaran. Menurut Ditjen Dikmenum (2004: 14) hanya ada satu kompetensi di ini yaitu sebagai berikut: Menguasai keilmuan dan keterampilan sesuai dengan materi pembelajaran dengan indikator sebagai berikut : Menguasai materi pembelajaran di bidangnya

\section{Komponen}

Kompetensi

Pengembangan Profesi. Kompetensi ini sangat berkaitan dengan kemampuan guru mata pelajaran dalam mengembangkan dirinya sebagai guru mata pelajaran yang profesional. Guru mata pelajaran harus bisa mengembangkan dirinya yang melalui penelitian-penelitian pendidikan demi kemajuan peserta didik dan kemajuan dirinya sendiri.

Menurut Pidarta (1990) dalam Pelangi (2005: 23) kepala sekolah merupakan kunci kesuksesan sekolah dalam mengadakan perubahan. Kegiatan untuk meningkatkan dan mengadakan perubahan. Kegiatan untuk meningkatkan dan memperbaiki program dan proses pembelajaran di sekolah sebagian besar terletak pada diri kepala sekolah tu sendiri. Lebih lanjut Pidarta (1990) menyatakan bahwa kepala sekolah memiliki peran dan tanggung jawab sebagai manajer pendidikan, pemimpin pendidikan, supervisor pendidikan dan administrasi pendidikan.

Dalam hal kinerja, kepala sekolah harus melaksanakan tugas utamanya menjadi kepala sekolah tersebut dengan penuh tanggung jawab. Penilaian kinerja kepala sekolah harus melaksanakan tugasnya yang berkaitan dengan kepala sekolah sebagai pendidik (edukator), kepala sekolah sebagai manajer, kepala sekolah sebagai administrator, kepala sekolah sebagai penyelia (supervisor) kepala sekolah sebagai pemimpin (leader) dan kepala sekolah sebagai enterpreneur (kewirausahaan)

Berdasarkan uraian masalah tersebut di atas maka Penulis selaku Kepala Sekolah terdorong untuk melakukan penelitian untuk memperbaiki kinerja dan wawasan guru mata pelajaran dalam pembelajaran di SMK Negeri 1 Sibolga. Sehubungan dengan keterbatasan peneliti, penelitian dalam hal ini hanya 
difokuskan pada supervisi eksternal saja, sehingga judul penelitian tindakan ini adalah "Pengaruh Supervisi Eksternal Dinas Pendidikan Kota Sibolga dalam Meningkatkan Kinerja Guru mata pelajaran Mata Pelajaran di Kelas SMK N 5 Medan Sibolga TP.2014-2015"

Permasalahan penelitian tindakan ini adalah sebagai berikut: (1) Apakah dengan supervisi Eksternal Dinas Pendidikan secara periodik dapat meningkatkan kinerja guru mata pelajaran dalam menyusun Rencana pembelajaran?; (2) Apakah dengan supervisi Eksternal Dinas Pendidikan secara periodik dapat meningkatkan kinerja guru mata pelajaran dalam pembelajaran?; (3) Apakah dengan supervisi Eksternal Dinas Pendidikan secara periodik dapat meningkatkan kinerja guru mata pelajaran dalam prestasi belajar siswa?; (4) Apakah dengan supervisi eksternal Dinas Pendidikan secara periodik dapat meningkatkan kinerja guru mata pelajaran dalam tindak lanjut hasil pembelajaran (remedial dan pengayaan)?; (5) Hipotesis tindakan dalam penelitian ini adalah "Kinerja guru mata pelajaran di kelas akan meningkat jika supervisi edukatif Eksternal Dinas Pendidikan dilaksanakan dengan sistematis dan proaktif"

\section{METODE}

Penelitian ini dilaksanakan di SMK Negeri 1 Kota Sibolga pada tahun pelajaran 2014/2015, dilaksanakan pada semester ganjil dan genap tahun pelajaran tersebut karena sebagian guru mata pelajaran belum memiliki kinerja yang diingin untuk peningkatan mutu pendidikan. Guru mata pelajaran yaitu Guru mata pelajaran PNS dan Guru mata pelajaran Tidak Tetap (Honorer) dan ijazahnya pun beragam, yakni, ada yang berijazah Diploma (D3), Sarjana (S-1) dan PascaSarjana (S2).

Selama penelitian tersebut peneliti mengumpulkan data awal, menyusun program supervisi, pelaksanaan supervisi, analisis dan tindak lanjut.

Data yang telah dikumpulkan dan kemudian dianalisis dengan menggunakan analisis kualitatif dan kuantitatif. Analisis kualitatif digunakan untuk menjelaskan perubahan perilaku guru mata pelajaran dalam pembelajaran dan perilaku supervisor dalam melaksanakan supervisi guru mata pelajaran. Adapun analisis kuantitatif digunakan unutk mengetahui keberhasilan guru mata pelajaran dan siswa berdasarkan kompetensi guru mata pelajaran yang telah ditetapkan oleh Kementrian Pendidikan dan Kebudayaan (Kemendikbud) sebagai berikut
a. Nilai 91-100 = Amat Baik (A) berhasil
b. Nilai 76-90= = Baik (B) berhasil
c. Nilai $55-75=$ Cukup (C) belum berhasil
d. Nilai 0- $54=$ Kurang (D) belum berhasil

\section{HASIL DAN PEMBAHASAN}

Hasil siklus pertama dapat dilihat pada tabel berikut ini.

Tabel 1 Hasil Perencanaan Siklus 1

\begin{tabular}{|c|c|c|c|}
\hline No & Indikator & $\begin{array}{c}\text { Jml. Guru mata pelajaran } \\
\text { Berhasil (Skor }>75\end{array}$ & $\begin{array}{c}\% \\
\text { Keberhasilan } \\
\end{array}$ \\
\hline 1. & Mendiskripsikan tujuan Pembelajaran & 54 & $78 \%$ \\
\hline 2. & Menentukan materi sesuai dengan kompetensi & 60 & 1070 \\
\hline 3. & Mengorganisasikan materi berdasarkan & 38 & $81 \%$ \\
\hline & urutan/kelompok & & $55 \%$ \\
\hline 4. & Mengalokasikan waktu & 69 & $100 \%$ \\
\hline 5. & Menentukan metode pembelajaran & 34 & $49 \%$ \\
\hline 6. & Merancang prosedur pembelajaran & 44 & $64 \%$ \\
\hline 7. & Menentukan media pembelajaran & 23 & \\
\hline 8. & Menentukansumber belajar yan sesuai berupa & 59 & $33 \%$ \\
\hline & buku,modul, lks dsb) & & $86 \%$ \\
\hline 9. & Menentukan teknik penilaian yang sesuai & 16 & $23 \%$ \\
\hline \multicolumn{3}{|c|}{ Rata-Rata Persentasi Keberhasilan } & $64 \%$ \\
\hline
\end{tabular}


Tabel 2 Hasil Melaksanakan Pembelajaran Tindakan Siklus 1

\begin{tabular}{|c|l|c|c|}
\hline No & \multicolumn{1}{|c|}{ Indikator } & $\begin{array}{c}\text { Jml. Guru mata pelajaran } \\
\text { Berhasil (Skor }>75\end{array}$ & $\begin{array}{c}\% \\
\text { Keberhasilan }\end{array}$ \\
\hline 1. & Membuka pelajaran dengan metode yang & 50 & $72 \%$ \\
2. & tepat & 38 & $55 \%$ \\
3. & Menyajikan materi pelajaran secara sistematis & & $19 \%$ \\
& Menerapkan metode dan prosedur & 13 & $91 \%$ \\
4. & pembelajaran yang telah ditentelukan & 63 & $41 \%$ \\
5. & Mengatur kegiatan siswa di kelas & 28 & $91 \%$ \\
6. & Menentukan media pembelajaran & 63 & $87 \%$ \\
7. & Menggunakan sumber belajar & 60 & $83 \%$ \\
8. & Memotivasi siswa dengan berbagai cara yang & 57 & $36 \%$ \\
9. & Mesitif & & $51 \%$ \\
10. & Menggukanakan interaksi dengansiswa bahasa yang komunikatif & 25 & $45 \%$ \\
11. & Menberikan pertanyaan dan umpan balik & 35 & $61 \%$ \\
\hline
\end{tabular}

Tabel 3 Hasil Menilai Prestasi Belajar Siklus 1

\begin{tabular}{|c|l|c|c|}
\hline No & \multicolumn{1}{|c|}{ Indikator } & $\begin{array}{c}\text { Jml. Guru mata pelajaran } \\
\text { Berhasil (Skor > 75 }\end{array}$ & $\begin{array}{c}\% \\
\text { Keberhasilan }\end{array}$ \\
\hline 1 & Menyusun soal/ Perangkat Penilaian & 53 & $77 \%$ \\
2 & Melaksanakan penilaian & 57 & $83 \%$ \\
3 & Memeriksa jawaban/Memberi skor & 47 & $68 \%$ \\
4 & Menilai Hasil belajar & 69 & $100 \%$ \\
5 & Mengolah hasil belajar & 47 & $68 \%$ \\
6 & Menganalisi hasil belajar & 44 & $64 \%$ \\
7 & Menyimpulkan hasil belajar & 47 & $68 \%$ \\
8 & Menyusun laporan hasil belajar & 69 & $81 \%$ \\
9 & Memperbaiki soal / perangkat penilaian & 69 & \\
\hline \multicolumn{2}{|c|}{ Rata-Rata Persentase Keberhasilan } \\
\hline
\end{tabular}

Tabel 4. Hasil Melaksanakan Tindak Lanjut Hasil Penilaian Siklus 1

\begin{tabular}{|c|l|c|c|}
\hline No & \multicolumn{1}{|c|}{ Indikator } & $\begin{array}{c}\text { Jml. Guru mata pelajaran } \\
\text { Berhasil (Skor > 75 }\end{array}$ & $\begin{array}{c}\% \\
\text { Keberhasilan }\end{array}$ \\
\hline 1 & Mengidentifikasi kebutuhan tindak lanjut & 41 & $59 \%$ \\
2 & Menyusun program tindaklanjut & 44 & $64 \%$ \\
3 & Melaksanakan tindak lanjut & 32 & $46 \%$ \\
4 & Mengevaluasi hasil tindak lanjut hasil & 29 & $42 \%$ \\
& penilaian & 22 & $32 \%$ \\
\cline { 2 - 3 } & Menganalisis hasil evaluasi program tindak & & $49 \%$ \\
\hline \multicolumn{2}{|c|}{ Ranjut hasil penilaian } & \\
\hline
\end{tabular}

\section{Hasil Pelaksanaan Siklus II}

Hasil siklus pertama dapat dilihat pada tabel berikut ini.

Tabel 5. Hasil Penentuan Perencanaan Siklus II

\begin{tabular}{|c|c|c|c|}
\hline No & Indikator & $\begin{array}{c}\text { Jml. Guru mata pelajaran } \\
\text { Berhasil (Skor }>75\end{array}$ & $\begin{array}{c}\% \\
\text { Keberhasilan }\end{array}$ \\
\hline
\end{tabular}




\begin{tabular}{|l|l|c|c|}
\hline 1. & Mendiskripsikan tujuan Pembelajaran & 69 & 100 \\
2. & Menentukan materi sesuai dengan kompetensi & 66 & 96 \\
3. & Mengorganisasikan materi berdasarkan & 66 & 96 \\
4. & urutan/kelompok & & \\
5. & Mengalokasikan waktu & 69 & 90 \\
6. & Mentukan metode pembelaran & 63 & 96 \\
7. & Menentukan media pembelajaran & 66 & 77 \\
8. & Menentukansumber belajar yan sesuai berupa & 53 & 96 \\
& buku,modul, lks dsb) & 66 & 96 \\
9. & Menentukan teknik penilaian yang sesuai & 66 & 94.22 \\
\hline
\end{tabular}

Tabel 6. Hasil Melaksanakan Pembelajaran Tindakan Siklus II

\begin{tabular}{|c|c|c|c|}
\hline No & Indikator & $\begin{array}{c}\text { Jml. Guru mata pelajaran } \\
\text { Berhasil (Skor }>75\end{array}$ & $\begin{array}{c}\% \\
\text { Keberhasilan } \\
\end{array}$ \\
\hline 1. & Membuka pelajaran dengan metode yang tepat & 57 & $83 \%$ \\
\hline 2. & Menyajikan materi pelajaran secara sistematis & 53 & 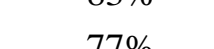 \\
\hline 3. & Menerapkan metode dan prosedur & 47 & $11 \%$ \\
\hline 4. & pembelajaran yang telah ditentelukan & 69 & $68 \%$ \\
\hline 5. & Mengatur kegiatan siswa di kelas & 53 & $100 \%$ \\
\hline 6. & Menentukan media pembelajaran & 69 & $77 \%$ \\
\hline 7. & Menggunakan sumber belajar & 69 & $100 \%$ \\
\hline 8. & $\begin{array}{l}\text { Memotivasi siswa dengan berbagai cara yang } \\
\text { positif }\end{array}$ & 63 & $100 \%$ \\
\hline 9. & Melakukan interaksi dengansiswa & 60 & $91 \%$ \\
\hline 10. & menggunakan bahasa yang komunikatif & 69 & $87 \%$ \\
\hline 11. & $\begin{array}{l}\text { Menyimpulkan pembelajaran } \\
\text { Menggunakan waktu secara efektif }\end{array}$ & 62 & $\begin{array}{r}100 \% \\
90 \%\end{array}$ \\
\hline & Rata persentase keberhasilan & & $88 \%$ \\
\hline
\end{tabular}

Tabel 7. Hasil Menilai Prestasi Belajar Siklus II

\begin{tabular}{|c|l|c|c|}
\hline No & \multicolumn{1}{|c|}{ Indikator } & $\begin{array}{c}\text { Jml. Guru mata pelajaran } \\
\text { Berhasil (Skor }>75\end{array}$ & $\begin{array}{c}\% \\
\text { Keberhasilan }\end{array}$ \\
\hline 1 & Menyusun soal/ Perangkat Penilaian & 69 & $100 \%$ \\
2 & Melaksanakan penilaian & 65 & $94 \%$ \\
3 & Memeriksa jawaban/Memberi skor & 69 & $100 \%$ \\
4 & Menilai Hasil belajar & 69 & $100 \%$ \\
5 & Mengolah hasil belajar & 65 & $94 \%$ \\
6 & Menganalisi hasil belajar & 63 & $91 \%$ \\
7 & Menyimpulkan hasil belajar & 63 & $91 \%$ \\
8 & Menyusun laporan hasil belajar & 69 & $100 \%$ \\
9 & Memperbaiki soal / perangkat penilaian & 69 & $100 \%$ \\
& & & $97 \%$ \\
\hline
\end{tabular}

Tabel 8. Hasil Melaksanakan Tindak Lanjut Hasil Penilaian Siklus II

\begin{tabular}{|c|c|c|c|}
\hline No & Indikator & Jml. Guru mata & $\%$ \\
& pelajaran Berhasil (Skor & $>75$ & Keberhasilan \\
\hline
\end{tabular}




\begin{tabular}{|c|l|c|c|}
\hline 1 & Mengidentifikasi kebutuhan tindak lanjut & 53 & $77 \%$ \\
2 & Menyusun program tindaklanjut & 57 & $83 \%$ \\
3 & Melaksanakan tindak lanjut & 50 & $72 \%$ \\
4 & Mengevaluasi hasil tindak lanjut hasil & 53 & $77 \%$ \\
& penilaian & & $83 \%$ \\
\hline & Menganalisis hasil evaluasi program tindak & 57 & $78 \%$ \\
\hline
\end{tabular}

Berdasarkan hasil penelitian diatas, peneliti membahasnya dari segi pengalaman peneliti pada saat menjadi supervisi pelajaran sebelumnya. Selain itu pembahasan didasarkan pada teori-teori yang sudah ada, baik berdasarkan pada referensi maupun dari ucapan ahli di bidang penelitian ini. Adapun pembahasan hasil penelitian ini adalah sebagai berikut.

Temuan pertama kinerja guru mata pelajaran meningkatkan ketika membuat perencanaan pembelajaran. Hal ini terjadi karena adanya kerja sama guru mata pelajaran mata pelajaran yang satu dengan lainnya dibantu oleh guru mata pelajaran senior yang ditugasi oleh kepala sekolah untuk mensupervisi guru mata pelajaran tersebut. Langkah-langkah yang dapat meningkatkan kinerja guru mata pelajaran dalam membuat persiapan pembelajaran adalah sebagai berikut

1. Guru mata pelajaran / supervisor Eksternal Dinas Pendidikan memberikan format supervisi dan jadwal supervisi pada awal tahun pelajaran atau awal semester. Pelaksanaan supervisi tidak hanya dilakukan sekali.

2. Guru mata pelajaran senior/ Supervisor Eksternal Dinas Pendidikan selalu menanyakan perkembangan pembuatan perangkat pembelajaran (mengingatkan betapa pentingnya perangkat pembelajaran).

3. Satu minggu sebelum pelaksanaan supervisi perangkat pembelaajran, supervisor/guru mata pelajaran senior menanyakan format penilaian. Jika format yang dierikan pada awal tahun pelajaran tersebut hilang, guru mata pelajaran yang bersangkutan disuruh memfotokopi arsip sekolah. Jika di sekolah masih banyak format seperti itu. Bersamaan dengan memberi/menanyakan format, supervisor meminta pengumpulan kelebihan dan kekurangannya.

4. Supervisor Eksternal Dinas Pendidikan memberikan catatan-catatan khusus pada lembaran untuk diberikan kepada guru mata pelajaran yang akan di supervisi tersebut.

5. Supervisor Eksternal Dinas Pendidikan tidak mencerminkan sebagai penilai. Supervisor Eksternal Dinas Pendidikan bertindak sebagai mitra dan teman. Supervisor Eksternal Dinas Pendidikan membimbing dan mengarahkan guru mata pelajaran yang belum bisa tetapi supervisor Eksternal Dinas Pendidikan juga menerima argumen guru mata pelajaran yang positif. Dengan adanya itu terciptalah hubungan yang akrab antara guru mata pelajaran dan supervisor Eksternal Dinas Pendidikan. Tentu saja ini akan membawa nilai positif dalam pelaksanaan pembelajaran.

Temuan kedua, kinerja meningkat dalam melaksanakan pembelajaran. Dalam tindakan ini ternyata dari 69 guru mata pelajaran hampir semuanya mampu melaksanakan pemelajaran dengan baik. Hal ini terbukti dari hasil supervisi. Langkah-langkah yang dilakukan untuk meningkatkan pelaksanaan pembelajaran berdasarkan penelitian tindakan ini dalah sebagai berikut :

1. Supervisor Eksternal Dinas Pendidikan yang mengamati guru mata pelajaran mengajar tidak sebagai penilai tetapi seagai rekan bekerja yang siap membantu guru mata pelajaran tersebut.

2. Selama pelaksanaan supervisi di kelas, guru mata pelajaran tidak menganggap supervisor Eksternal Dinas Pendidikan sebagai penilai karena sebelum pelaksanaan supervisi guru mata pelajaran dan supervisor Eksternal Dinas Pendidikan telah berdiskusi permasalahan- 
permasalahan yang ada dalam pembelajaran tersebut.

3. Supervisor Intertenal mencatat semua peristiwa yang terjadi di dalam pembelajaran, baik yang positif maupun yang negatif.

4. Supervisor selalu memberi contoh pembelajaran yang berorientasi pada Modern Learning.

5. Jika ada guru mata pelajaran yang pembelajarannya kurang jelas tujuan, penyajian, dan umpan-baliknya, supervisor Intertenal memberikan contoh bagaimana menjelaskan tujuan menyajikan, memberi umpan-balik kepada guru mata pelajaran tersebut.

6. Setelah guru mata pelajaran diberi contoh pembelajaran modern, supervisor setiap 2 atau 3 minggu mengunjungi atau mengikuti guru mata pelajaran tersebut dalam proses pembelajaran.

Temuan ketiga, kinerja guru mata pelajaran meningkatkan dalam menilai prestasi belajar siswa. Pada penelitian tindakan yang dilakukan ternyata pelaksanaan supervisi eksternal Dinas Pendidikan secara periodik memberikan dampak positif terhadap guru mata pelajaran dalam menyusun soal/perangkat penialian, melaksanakan, memeriksa, menilai dan memperbaiki soal. Sebelum diadakan supervisi edukatif secara kerja sama, guru mata pelajaran banyak yang mengalami kesulitan dalam melaksanakan penilaian. Langkah-langkah yang dilakukan dalam supervisi edukatif eksternal Dinas Pendidikan secara periodik yang dapat meningkatkan kinerja guru mata pelajaran adalah sebagai berikut :

1. Supervisor Eksternal Dinas Pendidikan berdiskusi dengan guru mata pelajaran dalam pembuatan perangkat penilaian sebelum dilaksanakan sepervisi.

2. Guru mata pelajaran melaksanakan penilaian sesuai dengan aturan yang telah ditetapkan bersama supervisor Eksternal Dinas Pendidikan, sebagai bentuk kerja sama dalam pembelajaran.

3. Guru mata pelajaran membuat kriteria penilaian yang berkaitan dengan penskoran, pembobotan dan pengolahan nilai, yang sebelum pelaksanaan supervisi didiskusikan dengan supervisor Eksternal Dinas Pendidikan.
4. Guru mata pelajaran menganalisis hasil penilaian dan melaporkannya kepada PKS (Pembantu Kepala Sekolah) Bidang Kurikulum.

Temuan keempat, kinerja guru mata pelajaran meningkat dalam melaksanakan tindak lanjut hasil penilaian prestasi belajar peserta didik. Langkah-langkah yang dapat meningkatkan kinerja guru mata pelajaran dalam supervisi edukatif eksternal Dinas Pendidikan yaitu sebagai berikut :

1. Supervisor Eksternal Dinas Pendidikan dan guru mata pelajaran bersama-sama membuat program tindak lanjut hasil penialian.

2. Guru mata pelajaran senior/supervisor Eksternal Dinas Pendidikan memberi contoh pelaksanaan tindak lanjut, yang akhirnya dilanjutkan oleh guru mata pelajaran dalam pelaksanaan yang sebenarnya.

3. Supervisor Intertenal dan atau guru mata pelajaran senior mengajak diskusi pada guru mata pelajaran yang telah membuat, melaksanakan dan menganalisis program tindak lanjut.

Temuan kelima, kinerja guru mata pelajaran meningkat dalam menyusun program pembelajaran, melaksanakan pembelajaran, menilai prestasi belajar, dan melaksanakan tindak lanjut hasil prestasi belajar siswa ternayata membawa kenaikan prestasi siswa dalam mengikuti Ulangan harian, Ujian Mid Semester dan Ujian Semester serta Ujian Akhir Sekolah.

\section{PENUTUP}

\section{Kesimpulan}

Pertama, tentang peningkatan kinerja guru mata pelajaran dalam menyusun rencana pembelajaran dapat disimpulkan sebagai berikut:

1. Supervisor Eksternal Dinas Pendidikan yang berasal dari teman sejawat atau guru mata pelajaran senior dapat mengakrabkan guru mata pelajaran dalam merumuskan tujuan khusus pembelajaran.

2. Supervisor Eksternal Dinas Pendidikan yang berasal dari teman sejawat dapat memudahkan komunikasi antar guru mata pelajaran dalam pembuatan rencana pembelajaran. 
3. Pelaksanaan supervisi edukatif Eksternal Dinas Pendidikan secara periodik dapat meningkatkan kinerja guru mata pelajaran dalam menyusun rencana pembelajaran dengan langkah-langkah sebagai berikut :

a. Guru mata pelajaran senior/supervisor Eksternal Dinas Pendidikan memberikan format supervisi pada awal tahun pembelajaran atau awal semester. Pelaksanaan supervisi tidak hanya dilakukan sekali.

b. Guru mata pelajaran senior selalu menanyakan perkembangan pembuatan rencana pembelajaran (mengingatkan betapa pentingnya rencana pembelajaran).

c. Satu minggu sebelum pelaksanaan supervisi rencana pembelajaran, supervisor/guru mata pelajaran senior menanyakan format penilaian.

d. Supervisor memberikan catatancatatan khusus pada lembaran untuk diberikan kepada guru mata pelajaran yang akan disupervisi tersebut.

e. Supervisor Eksternal Dinas Pendidikan dalam menilai perangkat pembelajaran penuh perhatian dan tidak mencerminkan sebagai penilai. Supervisor bertindak sebagai kolaborasi. Supervisor Eksternal Dinas Pendidikan membimbing, mengarahkan guru mata pelajaran yang belum bisa dan menerima argumen guru mata pelajaran yang positif. Dengan adanya hal tersebut, terciptalah hubungan yang akra antara guru mata pelajaran dan supervisor Eksternal Dinas Pendidikan. Tentu saja ini akan membawa nilai positif dalam pelaksanaan pembelajaran

Kedua, tentang peningakatn kinerja guru mata pelajaran dalam melaksanakan pembelajaran dapat disimpulaknsebagai berikut :

1. Supervisor Eksternal Dinas Pendidikan yang berasal dari Pengawas dapat; (1) mengakrabkan guru mata pelajaran dalam melaksanakan pembelajaran di kelas; (2) memudahkan komunikasi antar guru mata pelajaran dalam melaksanakan pembelajaran di kelas.
2. Pelaskanaan supervisi edukatif eksternal Dinas Pendidikan secara periodik dapat meningakatkan kinerja guru mata pelajaran dalam melaksnakan pembelajaran dengan langkah-langkah sebagai berikut :

a. Supervisor Eksternal Dinas Pendidikan yang mengamati guru mata pelajaran mengajar tidak sebagai penilai tetapi sebagai rekan kerja yang siap membantu guru mata pelajaran tersebut.

b. Selama pelaksanaan supervisi dikelas, guru mata pelajaran tidak menganggap supervisor Eksternal Dinas Pendidikan sebagai penilai karena sebelum pelaskanaan supervisi guru mata pelajaran dan supervisor telah berdiskusi permasalahanpermasalahan yang ada dalam pembelajaran tersebut

c. Supervisor Eksternal Dinas Pendidikan mencatat semua peristiwa yang terjadi didalam pembelajaran baik yang positif maupun yang negatif.

d. Supervisor Eksternal Dinas Pendidikan selalu memberi contoh pembelajaran yang berorientasi pada modern learning

e. Jika ada guru mata pelajaran yang pembelajarannya kurang jelas tujuan penyajian dan umpan baliknya, supervisor memberikan contoh bagaimana memberikan tujuan menyajikan dan memeri umpan balik kepada guru mata pelajaran tersebut.

f. Setelah guru mata pelajaran diberi contoh pembelajaran modern, supervisor Eksternal Dinas Pendidikan setiap 3 atau 4 minggu mengunjungi atau mengikuti guru mata pelajaran tersebut dalam proses pembelajaran.

Ketiga tentang peningkatan kinerja guru mata pelajaran dalam menilai prestasi belajar dapat disimpulkan sebagai berikut :

1. Supervisor Eksternal Dinas Pendidikan yang berasal dari Pengawas dapat memudahkan guru mata pelajaran dalam berkonsultasi dalam pembuatan perangkat penilaian. 
2. Supervisor Eksternal Dinas Pendidikan yang berasal dari pengawas dapat memudahkan komunikasi antara guru mata pelajaran dalam melaksanakan penilaian dan analisis hasil penilaian.

3. Pelaksanaan supervisi edukatif eksternal Dinas Pendidikan secara periodik dapat meningkatkan kinerja guru mata pelajaran dalam menilai prestasi belajar dengan langkah-langkah seagai berikut:

a. Supervisor Eksternal Dinas Pendidikan berdiskusi dengan guru mata pelajaran dalam pembuatan perangkat penilai seelum dilaksanakan supervisi.

b. Guru mata pelajaran melaksanakan penilaian sesuai dengan aturan yang telah ditetapkan bersama supervisor Eksternal Dinas Pendidikan sebagai kerja sama dalam pembelajaran.

c. Guru mata pelajaran memuat kriteria penilaian yang berkaitan dengan penskoran, pembobotan, dan pengolahan nilai, yang sebelum pelaksanaan supervisi didiskusikan dengan supervisor Eksternal Dinas Pendidikan.

d. Guru mata pelajaran mengalisis hasil penilaian dan melaporkannya kepada urusan kurikulum.

Keempat, tentang peningkatan kinerja guru mata pelajaran dalam melaksanakan tindak lanjut penilaian prestasi belajar siswa dapat disimpulkan sebagai berikut :

1. Supervisor Eksternal Dinas Pendidikan yang berasal dari pengawas dapat memudahkan guru mata pelajaran dalam melaksanakan tindak lanjut hasil penilaian prestasi belajar siswa.

2. Supervisor Eksternal Dinas Pendidikan yang berasal dari Pengawas dapat memudahkan komunikasi antar guru mata pelajaran dalam melaksanakan tindak lanjut hasil penilaian prestasi belajar siswa.

3. Pelaksanaan supervisi edukatif Intertenal secara periodik dapat meningkatkan kinerja guru mata pelajaran dalam melaksanakan tindak lanjut hasil penilaian prestasi belajar siswa dengan langkahlangkah sebagai berikut :
a. Supervisor Eksternal Dinas
Pendidikan dan guru mata pelajaran

bersama-sama membuat program tindak lanjut hasil penilaian.

b. Supervisor Eksternal Dinas Pendidikan atau guru mata pelajaran senior mengajak diskusi pada guru mata pelajaran yang telah membuat, melaskanakan, dan menganalisis program tindak lanjut.

Berdasarkan peningkatan kinerja guru mata pelajaran ternyata mempunyai pengaruh hasil prestasi belajar siswa siswa baik baik pada Ulangan harian maupun pada Ujian Mid semester, semester maupun Ujian akhir sekolah.

\section{SARAN}

1. Supervisi terhadap semua guru mata pelajaran perlu dilakukan secara periodik dan ditetapkan jadwalnya pada awal tahun ajaran baru (pada saat pembagian tugas)

2. Supervisi edukatif eksternal Dinas Pendidikan ternyata membawa peningkatan kinerja guru mata pelajaran dan hasil belajar siswa.

3. Supervisi edukatif akan bermakna jika supervisornya teman sejawat yang mampu pada mata pelajaran yang bersangkutan.

4. Kepala Sekolah memberikan kesempatan kepada guru-guru mata pelajaran yang dianggap mampu mensupervisi guru mata pelajaran yang lain.

5. Bagi Guru mata pelajaran bidang studi yang disupervisi hendak konsen dan serius dalam mengikuti kegiatan supervisi serta memenuhi arahan dan supervisi, guna meningkatkan mutu dan kinerja guru mata pelajaran.

6. Guru mata pelajaran hendaknya mengikuti perkembangan teknologi pendidikan modern misalnya dengan membuat bahan ajar berbasis IT dan memanfaatkan internet untuk meningkatkan kompetensi.

\section{DAFTAR PUSTAKA}

Arikunto, Suharsimi, Suhardjono, dan Supardi, 2006, Penelitian Tindakan Kelas, Jakarta, Bina Aksara

Suryosubroto, 2009, Proses Belajar Mengajar di Sekolah, Jakarta, Rineka Cipta

Zaenal Aqib, dkk, 2009, Penelitian Tindakan Kelas (PTK) untuk Guru SMP SMA $S M K$, Jakarta, Yrama Widya 
Jurnal TIK dalam Pendidikan, Vol. 7 No. 2 Desember 2020, p-ISSN: 2355-4983, e-ISSN: 2407-7488

Zaenal Aqib, dkk, 2009, Penelitian Tindakan Sekolah (PTS) untuk Pengawas, Kepala Sekolah dan Guru, Jakarta, Yrama Widya
Soetriono, dkk, 2007, Filsafat Ilmu dan Metodologi Penelitian, Yogyakarta, Andi Ofset. 